\title{
Subverting the narrative of the Lampedusa borderscape
}

\begin{abstract}
With this article I wish to challenge the concept of 'crisis', commonly associated with the arrival of irregularized migrants to the island of Lampedusa, by showing how this conception is usually the result of a fabrication and spectacle to which migrants become subjected, fuelling a 'moral panic' difficult to overcome. The understanding and representation of migrants as 'carriers of crisis' has inevitably undermined their dignity and rights as individuals. As a counter-narrative, this article explores a series of acts of resistance revolving around the issue of migration, where Lampedusa plays a central role, promoting the autonomy of migrants that is challenging the order of a securitized Europe. Through analyses of the grassroots documentary and theatre projects On the Bride's Side (Angliaro et al., 2014) and Queens of Syria (Fedda, 2013), this article finally explores the possibility of perceiving art about migrant experiences as a domain of struggle, through acts that I have defined as 'aesthetics of subversion', where those who are normally depicted as 'imperceptible bodies' become 'subjects of power', the power of subverting the narrative around their journey, their past and their desires for the future.
\end{abstract}

\section{CRISIS: A PROBLEMATIC LABEL}

It is not surprising if today the name 'Lampedusa' echoes with images of death, suffering, deportation and securitization, despite the island being one of the most popular touristic destinations in the South of Europe. This little

\section{KEYWORDS}

crisis

spectacle

migrant struggle

LampedusaInFestival

On The Bride's Side

Queens of Syria

aesthetics of subversion 
1. The vast majority of Eritreans and South Sudanese refugees are in fact relocated in neighbouring countries such as Ethiopia, Kenya, Sudan and Uganda. Only a small number of them try to cross the African continent and then the Sicilian channel in order to reach Europe. Besides, only 10 per cent of the irregular immigration in Europe comes from the sea. Most of the undocumented migrants overstay their visa and arrive to Europe by legal means
Italian piece of land located in the middle of the Mediterranean Sea has, in fact, become a hub from which to observe the dynamics of the current migratory processes, a place of experimentation with new strategies of patrolling and securitization and a stage for humanitarian interventions as a result of a narrative of 'emergency' that has characterized the so-called 'migrant crisis' during at least the past two decades. This narrative has been sustained and fuelled by a series of governmental and non-governmental interventions and media strategies that have justified the idea that Italy, and therefore Europe, is witnessing an invasion of desperate and potentially dangerous masses that are destabilizing the order of well-delimited and protected national spaces.

The label 'crisis' in relation to the current global passage that sees Europe as a final destination has become an over-determined signifier of a process that is gradually obfuscating the real reasons for the current diaspora from conflict areas. A series of scholars, who have recently offered a collective critical analysis of the term 'crisis', observe:

Labelling a complex situation (such as that of the contemporary dynamics of mass migration and refugee movements) as a 'crisis' and therefore as 'exceptional' tends to conceal the violence and permanent exception that are the norm under global capitalism and our global geo-politics, and may serve to perpetuate the conditions that have led to the purported 'emergency' in the first place.

(Heller 2015: 10)

In this un-exceptional 'emergency' of the passage of migrants in the Sicilian Channel, Lampedusa has become the ideal stage for the spectacle of a crisis, where the real actors of the passage, those who undertake the perilous and 'irregular' journey, are commonly kept behind the scenes. They are considered the 'carriers of a contagious malady', as also highlighted by De Genova, of the crisis itself, embodied, as it has become, in the usually shabby and disempowered figure of the migrant, and ultimately in corpses floating in the Mediterranean Sea or washing up on the shores of Europe: 'wherever they are heading, they seem to bring the "crisis" with them' (2015: 20).

In line with this idea of migrants as carriers of crisis, terms such as 'mass', 'swarm', 'flood' and 'invasion' have been indiscriminately used to define people on the move; and the'spectacle of statistics' (Stierl 2015: 22) has been consistently applied to justify stricter patrolling actions, without stressing the fact that these numbers do not justify a crisis. ${ }^{1}$ The spectacle of statistics serves, in fact, a precise purpose, which Stierl addresses in a straightforward way:

The spectacle of numbers assists in the construction of illegalized migration as 'the problem' to which border and other immigration law enforcement measures must be addressed, while the political disorder and economic catastrophes that migrants and refugees have fled are relegated by implication to the status of a mere externality, someone else's responsibility'elsewhere'.

The direct consequence of this process of illegalization of migrants is a toxic representation of them in the public discourse as de-individualized aggregations, without any political agency, only capable of disrupting the constituted sacrosanct 'order' of the bordered States. 
Another aspect that has contributed to the deconstruction of individual subjectivity of migrants is the gradual concealing of the violence of the securitarian system, through a travesty of humanitarian action. The Italian operation Mare Nostrum and Frontex's Triton, for instance, have both been framed as rescue missions in the Mediterranean, aimed at saving as many lives as possible from the peril that their very military border protection enforcement entails. Within this humanitarian framework migrants (especially the latter) have been reconfigured as victims, rather than as mere 'criminals', but in no way has the socio-political construction of them as illegal and irregular been undermined. ${ }^{2}$ They still remain 'susceptible for detention and deportation' (Tazzioli 2015a: 26).

In line with this approach to immigration as a carrier of crisis, the island of Lampedusa has been increasingly militarized: the centre for identification and expulsion, present on the island, has recently been turned into a hotspot and has put in place a strict system of screening and fingerprinting migrants, often against their will. ${ }^{3}$ This pressure promoted by the narrative of emergency, which is becoming permanent rather than exceptional, is clearly the result of a crisis of migration management and border control that is being undermined by the migrants' claim to autonomy and subjectivity as they undertake an irregular journey that breaches borders and challenges the socio-political order of Europe. De Genova suggests that these acts of disobedience are:

An opportunity for re-thinking and re-inventing border struggles toward the ends of reinforcing and enhancing the elementary human freedom of movement [...]. In this respect, the 'crisis' of the European border regime provoked by the myriad autonomies and subjectivities of human mobility presents us with a moment replete not only with as-yet unresolved conflicts but also unimagined potentialities.

Such potentialities will be exemplified and discussed in the following pages.

\section{LAMPEDUSA, A SITE OF MIGRANT STRUGGLE}

Despite the regime of control in place in Lampedusa, the island has demonstrated the ability to operate as a space of resistance. In various ways, a re-signification of migrants from 'imperceptible bodies' to 'subjects of power' has been promoted on the island (Papadopoulos et al. 2008). The act of becoming subjects of power is here intended to signify'a political practice through which social actors escape normalising representations and reconstitute themselves in the course of participating and changing the condition of their material corporeal existence' (Papadopoulos et al. 2008: xviii).

From this perspective, the marginal European space Lampedusa inhabits may become a position from which a critical response to dominion may be possible, a marginality that in bell hooks' words functions 'as a site of resistance' (1990: 341). Lampedusa is in fact enacting its political and social struggle through local and migrants'voices, which are promoting a counter-positioning of the so-called migration 'crisis' by claiming human dignity and the right to exist (Mazzara 2015: 454).

Among the acts of disobedience and counter-mapping (Tazzioli 2015b), to which Lampedusa has played an important role, we need to recall all those moments (e.g. on 16 July 2013 and on 20 December 2015) in which migrants
2. To read further about the so-called humanitarian 'crisis', see Watson (2009), Walters (2011), Fassin (2012), Perkowski (2016), Ticktin (2011), Cuttitta (2015).

3. To read further about the Hotspot approach in Lampedusa see Tazzioli and Garelli (2016). 
4. The EU Dublin III Regulation determines that the EU member state responsible for the asylum claims is the one the asylum seeker first enters, Italy in the case of those entering Europe via Lampedusa.

5. Starting from last year the collective decided to change the format of the festival and to replace the one-week film competition with a series of cultural events that are spread throughout the whole year.

6. To read more about Askavusa, see the article by Ilaria Vecchi in this issue.

7. An extract of Zakaria and Dagmawi's travel diaries can be read in this issue, in the section 'Tales of Journeys'

8. The Archive of Migrant Memories (Archivio memorie migranti) is based in Rome and aims to support migrants' voices by encouraging them to use art as a political tool. An article by Alessandro Triulzi, director of the Archive, can be read in this issue.

9. The project's creator was the Association Melting Pot Europa. They involved more than 70 cities and organized online assemblies to draft the Charter (they used the open source DucuWiki tool of Wikipedia to let everyone read and edit the draft Charter). During the second day, the Charter was approved by all the networks and individuals who took part in the Mediterranean Meeting. have occupied the main streets to demonstrate against the inhumane conditions under which they were kept inside the camp and in order to reject fingerprinting and repatriation that would restrict their freedom to move. ${ }^{4}$ On other occasions in 2009, 2011 and 2016, migrants, mostly Tunisians, set fire to a portion of the camp. These unpredictable and destabilizing gestures are powerful means with which the otherwise concealed mechanism of securitization, which manufactures the above-mentioned crisis, and the ability of migrants to perform their autonomy of migration is revealed (Mezzadra 2011). Such acts of disobedience put their struggle under a magnifying glass and, to use Tazzioli's words, 'shed light on localized and specific movements which dislodge the supposed stability of political concepts and spaces' (Tazzioli 2015b: 149).

The migrants' struggles have found wide support and visibility within the island of Lampedusa, especially among the members of the local collective called Askavusa (which means 'barefoot woman' in Sicilian dialect). In 2009, this collective was founded by a group of activists and artists, mostly from the island, as a form of struggle itself, resisting the opening of a new centre for identification and expulsion (CIE). Ever since, Askavusa has worked tirelessly to produce a counter-narrative around the issue of migration on Lampedusa. Their activism has promoted a series of initiatives where the migrants' struggles have been made visible. In particular, the LampedusaInFestival, a film festival organized every year ${ }^{5}$ by the collective, has functioned as a hub for discussion and contestation of the current border enforcement and spectacle performed on the island. ${ }^{6}$ The festival has involved artists, writers, activists and academics from all over the world, all sharing a genuine interest in the possibility of developing a way to subvert the border politics and the consequent cruel treatment of migrants in the name of human rights and migrant autonomy. What makes this festival extremely important for the process of autonomy of migration is the fact that migrants themselves have been involved at various levels in the making of the event itself and in the delivery of its counter-narratives. Among others, the performer and writer Mohamad Ba and the film-makers Dagmawi Yimer and Zakaria Mohamed $\mathrm{Ali}^{7}$ have made their work known to an engaged and diverse public attending the festival. Yimer and Mohamed Ali, in particular, have experienced the passage of the Sicilian Channel in one of the many 'boats of death' approaching the shores of Europe via Lampedusa and have managed to retrieve agency thanks to the support of the Archive of Migrant Memories. ${ }^{8}$ As Chiara Brambilla highlights in an article revolving around this specific yearly event, the LampedusaInFestival has the potential to critically question the Lampedusa borderscape:

The LampedusaInFestival reveals that migrants are gradually contributing to overcoming the binary opposition between oppression and resistance at the EU southern external border, highlighting the urgency to focus our attention on a critical questioning of the ways in which more ambiguous, subtle strategies for existence and living in and across the Euro/African borderland are constructed by migrants, despite violent and oppressive border and migration regimes.

(Brambilla et al. 2015: 117)

Another example that expresses a'disobedient gaze' (Pezzani and Heller 2013) and has used Lampedusa as a'site of resistance' is the Charter of Lampedusa, ${ }^{9}$ a transnational declaration compiled on the island in 2014, involving various North African and European actors - associations, organizations, 
individuals - who gathered on the island from 31 January to 2 February 2014, after the umpteenth tragedy in the Mediterranean Sea on the 3rd and 11th of October 2013, causing the death of hundreds of migrants coming from the shores of Libya and attempting to reach Lampedusa. The Charter is divided into two parts: the first part lists the 'founding principles through which it aims to develop the struggles and actions inspired by the Charter', and the second part presents a 'response to current migration policies and militarization of national borders' (Carta di Lampedusa, n/d). The premise of the Charter is that all individuals have the same rights, against the global injustice perpetuated by the EU policies that have chosen Lampedusa as the location of their enforcements with insurmountable consequences also for the inhabitants. In the preamble of the Charter, we read:

The Charter is not intended as a draft law, legislative proposal or as a petition to governments. All the groups and individuals who undersign the Charter of Lampedusa commit to putting it into practice and to defending its principles through our endeavours, in the ways, languages and actions that each of us considers relevant, whether or not the Charter obtains recognition by current state and/or supra-state institutions.

(Carta di Lampedusa, n/d)

The Charter, which can be downloaded from its website in several languages, represents a bottom-up initiative that aims at challenging the prejudices around migration and the military approach that has been adopted. Among its principles listed in the first part are 'freedom of movement', 'freedom to self-determine one's place of residence', 'freedom to stay', 'freedom to plan a new life when movement is necessary', 'personal freedom' and 'freedom to resist'. Despite its good intentions and the willingness to involve a diverse public, the Charter failed to include, in this space of resistance and in the compiling of its draft, migrants, refugees and asylum seekers themselves. In so doing, as Rinelli observes, 'there is a risk of reifying the same old problem of exclusion of the space of appearance for migrants that reminds one of Spivak's famous dilemma: Can the Subaltern Speak? [...] Is this' - Rinelli asks - 'then the only way the plurality can take form? Are migrants, then, socially and politically dead, waiting for entitled citizens to breathe life into them?' (2016: 126).

An initiative that involves migrants more directly in the struggles and where Lampedusa functions as an empowering topos is represented by all the collectives around Europe organized by migrants, refugees and asylum seekers, who have arrived in Europe via Lampedusa and have managed to move to other countries than Italy, after their temporary residence permit expired. These individuals are now claiming the right to work and to be recognized as citizens in countries where they wish to establish their new homes. Among these collectives we should mention Lampedusa in Hamburg ${ }^{10}$ and Lampedusa in Berlin, ${ }^{11}$ both located in the respective German cities and both providing a space of resistance for all those migrants who have been denied the right to stay. These collectives have used the urban spaces of those cites in order to express their struggles and disobedience. Such spaces represent, to use Tazzioli's words, 'spaces in action' where a process of counter-mapping is performed. These spaces, in fact, escape any possible 'cartographic order':
10. Website of the collective: http:// lampedusahamburginfo/ Accessed 1 August 2016

11. Facebook page of the collective: https:// www.facebook.com/ lampedusainberlin/. Accessed 1 August 2016 
12. A documentary by Mauro Mondello called Lampedusa in Berlin tells the story of that occupation and struggle that ended in April 2014, when the German police cleared the self-organized refugee camp set up in the square.
Lampedusa in Hamburg evidently does not correspond to any place 'on the map', but it is an enacted space they travelled and in some way produced. Simultaneously, Hamburg refers to a claim, the claim for a space that is not already there: a space for them to stay. The Lampedusa in Hamburg collective contributes to instantiate a temporal frame of migrant struggles, going beyond the punctual moment of their spatial presence in the city of Hamburg, insofar as their claim for space is articulated on their common journey from Libya.

(Tazzioli 2015c)

These collectives promote a series of initiatives - also supported by local organizations and private citizens - which have made their struggles visible in various ways. Initiatives include demonstrations, occupations (e.g. the occupation of Oranienplatz ${ }^{12}$ in Berlin in 2012 as a form of resistance to the Residenzpflicht, a law that forbids migrants to move freely in Germany while waiting for the result of their asylum claim or residence permit), and protests aiming at raising awareness about the issue of invisibility and lack of rights of migrants in Europe. The two collectives are examples of an articulation of the struggle in terms of citizenship that, as Rygiel argues, 'draws attention to the ways in which migrants assert themselves as political subjects by making claims against certain perceived injustices and inequalities and through collective action, articulating a vision of a different future' (2011: 6, original emphasis).

In the next part of this article, I argue (as I have done elsewhere; e.g. Mazzara 2015) that this vision, which Rygiel suggests can be expressed by migrants as political subjects, finds a powerful soapbox in the domain of aesthetics that is able to articulate a new narrative that may contribute to emancipating migrants from the burden of being the carriers of a fabricated crisis.

\section{THE AESTHETICS OF SUBVERSION IN AND FROM THE LAMPEDUSA BORDERSCAPE}

Following on from my discussion of the potential for subverting the discourse around migration exemplified by the struggles of migrants who have used Lampedusa as a site of resistance through their protests, occupations and demonstrations, I want to refer to another possible expression of that very struggle by considering another form of political 'dissensus' (Rancière 2010) that derives from art and its ability to breach mental, virtual and factual borders. In the following, my examples will be two cases of what I have called the 'aesthetics of subversion' (Mazzara 2015): the crowd-funded film-documentary, On the Bride's Side (Angliaro et al., 2014), and the grassroots theatre project and documentary, Queens of Syria (Fedda, 2013).

Io sto con la sposa (On the Bride's Side) was developed following a series of coincidental encounters that led the Italian journalist Gabriele Del Grande and film director Antonio Angliaro and the Palestinian Syrian poet and writer Khaled Soliman Al Nassiry to join forces and give voice to an extraordinary example of border breaching and a disobedient act of dissensus. In October 2013, Del Grande and Al Nassiry were at the Porta Garibaldi Station in Milan when a man who overheard them speaking Arabic approached them to ask information about how to get to Sweden by train. They soon learnt that the man was called Abdallah Sallam. He was a Syrian Palestinian and had escaped the civil war, surviving one of the deadliest journeys across the Sicilian Channel: 34 people had 
died and 250 went missing, when on 11 October 2013 their boat capsized just a few miles off the shores of Lampedusa. ${ }^{13}$ Given their long-standing dedication to human rights and refugee issues, Del Grande and Al Nassiry felt compelled to do something for this man and the story of those who, like him, were trapped in the limbo of irregularization despite their rights to flee from conflict areas and their desire to settle in the country of their choice, in this case Sweden. Del Grande and $\mathrm{Al}$ Nassiry decided to involve the Italian director Angliaro in a project that they, at that point, could not have imagined would bring them to the 71 Venice International Film Festival, where they were conferred three awards. ${ }^{14}$ The project that led to the making of a documentary started with the realization that the best way of supporting Abdallah and a few more asylum seekers in Milan, who came from Syria and Palestine and were trying to reach Sweden, was to help them make the journey, to join them and make a record of it.

But how to cross Europe with no documents? How to dispel the suspicion of being the 'carriers of the crisis' that migrants usually embody? The solution that Del Grande, $\mathrm{Al}$ Nassiry and Angliaro found was an extremely successful act of aesthetic subversion that led to the breaching of all borders and fences that hindered their journey: they simply staged a fake wedding, and who would stop a wedding?

The wedding party consisted of five Syrian and Palestinian-Syrian migrants who refused being fingerprinted in Italy in order to reach Sweden and claim asylum there, against the Dublin Regulation. They were, apart from Sallam, who played the groom, Ahmad Abed and his wife Mona Al Ghabra, and Alaa Al-Din Bjermi and his son M. C. Manar. A Syrian Palestinian activist friend, Tasneem Fared, holding regular documents, ${ }^{15}$ offered to play the bride and to accompany the crew on this very risky journey. The party was joined by a motley group of people recruited by the three directors through an e-mail marked TOP SECRET. Thirteen journalists, aid workers, researchers and social organizers said yes, risking up to fifteen years in jail if charged with aiding illegal immigration, according to European Union immigration law. ${ }^{16}$

The wedding party started their journey from Milan on 14 November 2014 when twenty-three people, Italians, Syrians and Palestinians, wearing their best clothes met to join a bride and a groom on the journey that would bring them safely to Sweden on 18 November, after successfully crossing, by car, train and on foot, more or less patrolled borders - in France, Luxembourg, Germany and Denmark - without incurring any major problem despite breaching the law (Figure 1). As a result, a documentary was assembled out of the recordings from four intense days, and the production was made possible by a crowd-funded campaign that in a few months managed to collect 98,151 Euros (more than the set target, which was 75,000), a clear indicator that people are eager to know more and beyond what the media and political discourse construct around the 'migrant crisis'. ${ }^{17}$

Planning the journey involved a process of 'polishing' the refugees according to western standards: hairdressers, barbers, ties, shirts, suits and, of course, a wedding dress. The masquerade served an important purpose: to conceal any possible suggestion of refugees and migrants as carriers of the crisis and to disguise an appearance that could lead to a 'moral panic' (Cohen 2011), which is, after all, the result of the fragility of every human being. As Bauman recently stressed, 'those nomads - not by choice but by the verdict of a heartless fate - remind us, irritatingly, infuriatingly and horrifyingly, of the (incurable?) vulnerability of our own position and of the endemic fragility of our hard-won well-being' (2016: 16).
13. This shipwreck followed another one on the 3 October when over 360 deaths were reported

14. The awards are the Fedic Awards, the Hrns Human Rights Nights Award and the Sorriso Diverso Award.

15. Tasnin had fled from Yarmouk and emigrated to Spain She held a German passport so was free to move in Europe.

16. ART. 12 D. L. VO 286/98, art.12 comma 1 e 3 .

17. The documentary was featured in many of the biggest international documentary festivals around the world (IDFA, HotDocs and DocEdge, to name just a few). It has also been screened in 36 countries worldwide, broadcasted on Italy's SKY channel, and on Al Jazeera English. 
18. Euripides' play is set at the fall of Troy, and is written to express an anti-war protest attacking the violent suppression of the island of Melo from the city of Athens, that caused the loss of all men, while women and children were sold into slavery. The play explores the fears of the Trojan women as they contemplate a life of exile and slavery.

19. The original idea for this adaptation came from British writer Charlotte Eagar who together with her husband the filmmaker William Stirling and film producer Georgina Paget decided to embark in a modern adaptation of the Trojan Women and decided to do it with Syrian women, acknowledging the similar violence experienced by the Euripides' women and the women refugees. The project was supported by Refugees Production. They recruited the women by going around UNHCR food queues and community centres in Jordan, which is home to more than 650,000 Syrian refugees. In particular, they approached the Queen Zain al-Sharif community centre in Hashmi Shamali (Eager 2016).

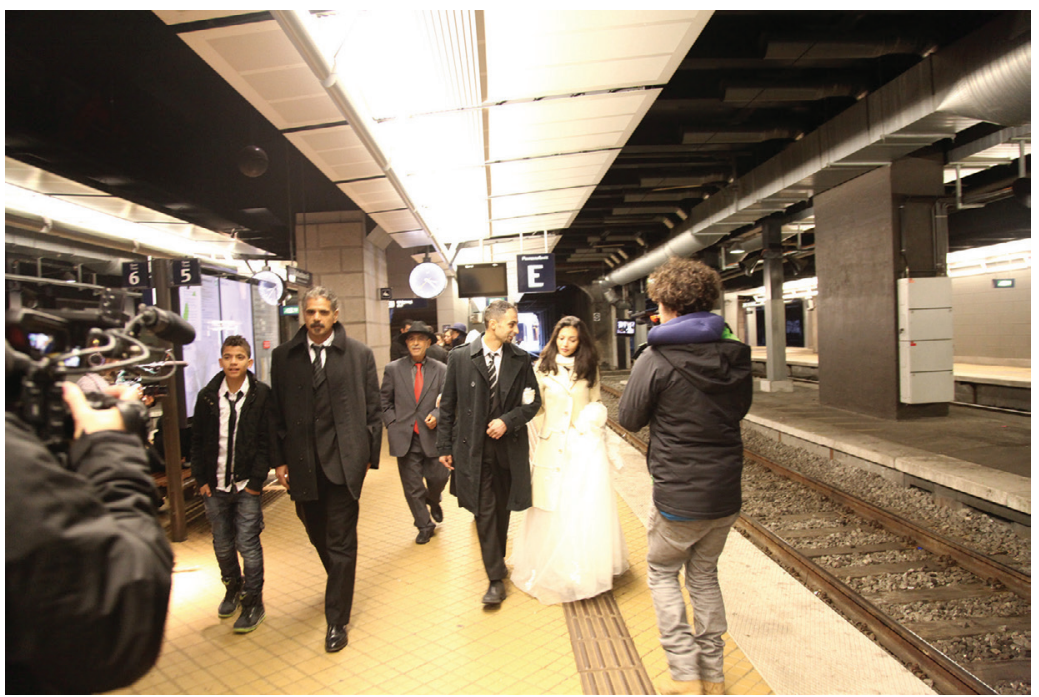

Figure 1: On the Bride's Side, The wedding party has finally arrived in Sweden, 2015 (C).

Wearing a wedding dress can do no harm and cannot spoil the polished imaginary world we like to live in. The police, in fact, never stopped the party on the move. Refugees and migrants were able to perform their struggle through a masquerade that ridiculed the border system in place in Europe and at the same time made the refugees free to cross the borders as individuals with stories, desires and hopes about which we learn by watching the documentary, where names replace numbers and where the usually victimized migrants become disobedient heroes (Figure 2). In several acts of subjectification, the protagonists of the journey take the word and utter their anger and frustration, such as when the young Manar breaks out in a rap in a cafe in Bochum, or when Abdullah recites the names of some of the 250 victims of the shipwreck he survived and that he managed to write in a piece of paper during the sea crossing. This is how On the Bride's Side subverts the narrative of the 'crisis' of migration and offers a unique view on the commonly silenced and unnamed protagonists of the Mediterranean passage, empowering them through acts of dissensus.

Another interesting and powerful example of migrant struggle comes from Jordan and Syria and, despite not being directly connected to the island of Lampedusa, it reveals an important moment of redemption for migrant subjects, who, like those who pass through Lampedusa, are forced to leave behind their homes, families and country, without knowing whether a return will ever be possible. Their present is an eternal limbo of denied rights, made of misery, frustration and memories of a homely and domestic setting.

The struggle I am referring to here - like On the Bride's Side - exemplifies an aesthetic of subversion that uses art as a political tool. In this case, the project involves a documentary directed by Yasi Fedda entitled Queens of Syria, which chronicles the making of a theatre play, a modern adaptation of Euripides' The Trojan Women ${ }^{18}$ directed by Syrian director Omar Abu Saada with the assistance of acting coach Nanda Mohammad and casting 23 Syrian women refugees who live displaced in Jordan. ${ }^{19}$ 


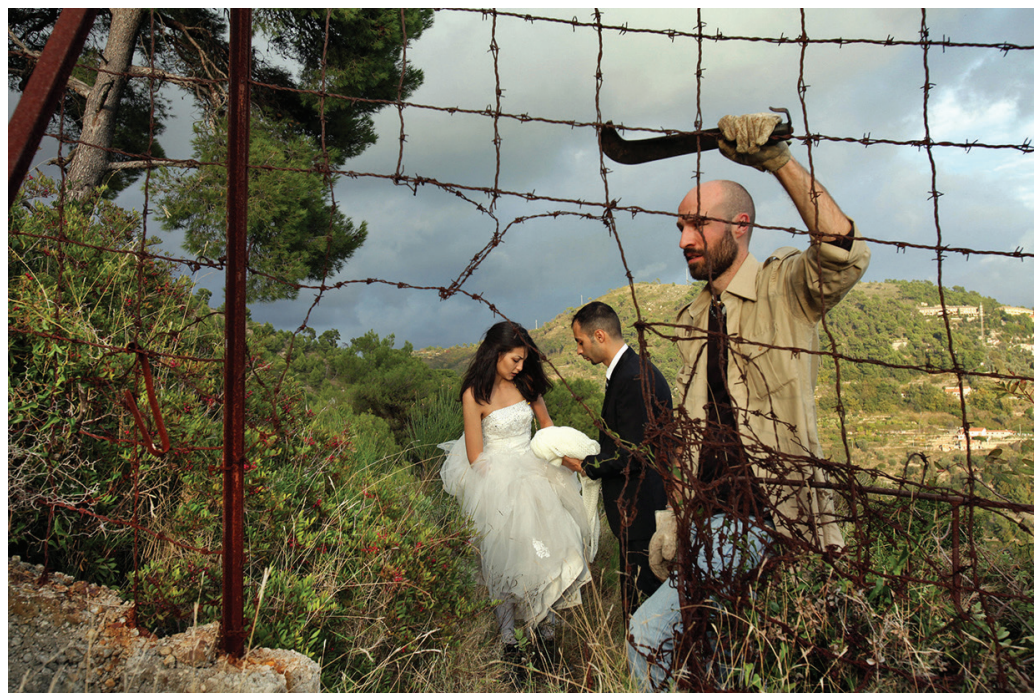

Figure 2: On the Bride's Side, The pretend bride and groom cross the border between Italy and France, 2015 (C).

The theatre project, The Syrian Trojan Women Project, required a commitment of seven weeks of rehearsals and workshops before curtain time. ${ }^{20}$ Sixty women, with no previous acting experience, originally signed up, but only 23 remained until the end. Those who quit did so for various reasons: some were afraid of repercussions to other members of their families remaining in Syria; some others' husbands were not comfortable with the fact that their wives would appear onstage. All women appearing in the documentary wear hijabs or niqabs. Their eyes are visible and are the real actors of the struggle.

The documentary shows the making of an empowering project for the Syrian women who took part. It documents the moment of realization that their story echoes so forcefully Euripides' tragedy, which talks about the destruction of Troy and gives voice to the sufferance of the women, whose husbands have been killed, leaving them alone to face displacement and enslavement by their enemies. The Syrian Queens find to their surprise that they share many emotions with the Trojan Women, and when reading Euripides' text they identify with Hecuba and Cassandra. As one of the participants observes,

Hecuba is so close to me [...] she lost everything she owned. She lost her children and her family [...] It's like us. She was a queen in her house. Her house was her kingdom, she ran it as she pleased. Hecuba says 'I used to run this place but now I am nothing'. That's us now.

(Fedda 2013)

The acting workshops, led by Nanda Mohammad and filmed for Fedda's documentary, work as moments of revelation for the Syrian women: they are asked to breach their personal borders, to engage with each other's emotions and to sense a freedom of expression they do not normally experience. The therapeutic workshops help the Syrian women to start and believe in their struggle expressed through acts of storytelling that mingle with Euripides' text,
20. The play was staged at the National Centre for Culture and Arts in the Jordanian capital of Amman. 
21. 'Reham and the other 12 cast members landed at Heathrow on July 3. They had left Amman at $4 \mathrm{am}$. There was Reem, Waed and Anwar, the three twenty something student daughters of a Damascus lawyer, and their mother Khowla, who had left behind five other children in Amman to accompany her daughters. There was Sham, who had her own pharmacy in Damascus before she her architect husband and their four children were forced to flee. There was Maha, the wife of a Damascus travel agent, who gave birth to their third child in a hospital ward in the middle of a bombardment while medical staff sheltered in the cellar. There was Hannan, who had left her husband and many children behind; Mais, whose husband had a chain of kitchensupply shops in Syria; and Diana, who says how much she misses being with her family at Ramadan. There was Rasha, who calls her children the "jasmine crowns"; Fatima and Faten, who is six months pregnant'. (Eager 2016) to the extent that it is almost impossible to discern the difference between the two stories: they complement each other and tell a universal story of suffering beyond time and space.

The women are asked to remember what they liked the most of their home country: its smells, their homes, their relatives. The sense of nostalgia is so strong at times they cannot help getting emotional. In one of the workshops, the Syrian women are asked to make a map of all the places they have moved into in the year before ending up in Jordan, and to list all the objects that they lost in those passages. The list is endless and allows the women to realize how much they have faced, while visualizing and talking about it with the other women made their losses easier to comprehend and bear.

The documentary consists of observations, direct interviews and footage of the women's everyday lives outside the anonymous place where the workshops happen. All this is cross-cut with scenes from the actual play, where the clearly emotional Syrian women, all black-dressed, face the audience while one by one, with broken voices, they tell their very personal stories of loss, violence and brutality, or read aloud from letters they have written for someone they left behind in Syria.

The Syrian Trojan Women Project did not finish with the documentary of the making of the play in Amman. One of its most extraordinary aspects is, in fact, its international tour that started in July 2016 in London thanks to the collaboration between Refugee Production, Developing Artists and the Young Vic, and despite the many difficulties with obtaining visas for the Syrian actresses. The UK version of the play was directed by Zoe Lafferty and cast thirteen women mostly from the original group who appeared in the documentary, but also a few new faces. ${ }^{21}$

I attended the show at the Young Vic on the 8th of July and was struck by the powerful struggle presented in this play, whose strength is shouted to the audience through the Greek Chorus from the very beginning: 'Lift up your head from the dust! Heave up from the earth the weight of your misery, you whom the Gods have cursed. Some agonies are beyond telling, and some must be told' (Eager 2016).

The Choric lament overwhelms the audience with stories that hurt and terrify. The storytelling is in Arabic, subtitled in English, and a screen in the background lights up at times - replacing the action on the stage - showing two parallel videos of women as if interviewed by someone who cannot be seen.

A peak moment of Queen of Syria arrives towards the end, when Reem, one of the women, addresses the audience directly in English to say:

I am not here to entertain you or sing a song. I have a rage and a message to pass to you. We come from the Troy of this age [...] hundreds of thousands of victims [...] millions of refugees [...] everyone wants to bomb us but no one wants to accept us into their homes [...] only the sea opens his arms to us without any preconditions [...]. When did it become normal to kill people?

(Eager 2016)

And the message becomes even clearer when in an ironic tone mocking journalists and other people approaching them in the West, Reem says, 'No, no, that's not sad enough'.'How come you have a smartphone?'. 'Can we make a play about your story?'. It is with this last question that the Queens of Syria take possession of the play itself, transgressing any boundaries between themselves 
and the audience and sending a final message, which is ultimately an act of subversion, a political act that includes us as spectators of the fabricated crisis they'carry' and of which we are all responsible.

In this act of inclusion, of 'intercultural relationality' (Bal 2016: 156), the Queens of Syria make sure their performance becomes a political struggle that reconfigures the 'distribution of the sensible'; to use Rancière's terms, they 'make heard as speakers those who had been perceived as mere noisy animals' (2009: 24-25), and they do so by sharing in their own language, personal and intimate moments of their daily life before and after the violation of war.

As a site of resistance and struggle, art is able to breach physical and virtual borders, producing a counter-narrative that is otherwise concealed by the hegemonic discourse of the narrative of crisis. Art, as in the case of On the Bride's Side and Queens of Syria, has the power to subvert the spectacle and put the observers in an unusual and at times uncomfortable position, where they are asked to re-organize the unspeakable and the invisible, what they - before this exposure - commonly identify with a carrier of crisis.

As I have showed in this article, Lampedusa has in many ways played an important role in this subversion, and it is thanks to this resistance that the island can be re-imagined as a place that goes beyond the spectacle of the crisis.

\section{REFERENCES}

Angliaro, A., Del Grande, G. and Al Nassiry, K. S. (2014), On the Bride's Side, Roma: DocLab.

Bal, M. (2016), 'In your face: Migratory aesthetics', in S. Pultz Moslund, A. Ring Petersen and M. Schramm (eds), The Culture of Migration: Politics, Aesthetics and Histories, London and New York: I. B. Tauris, pp. 147-69.

Bauman, Z. (2016), Strangers at Our Doors, Cambridge: Polity Press.

Bischoff, C., Falk, F. and Kafehsy, S. (2010), Images of Illegalized Immigration, Piscataway, NJ: Transaction Publishers.

Bonfiglioli, C. (2015), 'Of weddings and borders', Open Democracy, https:// www.opendemocracy.net/can-europe-make-it/chiara-bonfiglioli/ of-weddings-and-borders. Accessed 1 August 2016.

Brambilla, C., Laine, J., Scott, J. W. and Bocchi, G. (2015), Navigating the Euro/ African border and Migration Nexus through the Borderscapes Lens, Bordering: Imaginations and Practices of Border Making, London: Ashgate.

Charter of Lampedusa (n/d), http://www.lacartadilampedusa.org. Accessed 1 August 2016.

Cohen, S. (2011), Folks Devils and Moral Panics: The Creation of the Mods and Rockers, London: Routledge.

Cuttitta, P. (2015), 'Humanitarianism and migration in the Mediterranean borderscape', in C. Brambilla et al. (eds), Bordescaping: Imaginations and Practices of Border Making, Farnham: Ashgate, pp. 131-39.

Eager, C. (2016), 'A modern tragedy told by the "Queens of Syria"', http:// www.ft.com/cms/s/2/4f6e3a0c-4948-11e6-b387-64ab0a67014c.html. Accessed 1 August 2016.

Fassin, D. (2012), The Humanitarian Reason: A Moral History of the Present, Berkeley and Los Angeles: University of California Press.

Fedda, Yasi (2013), Queens of Syria, Munster: Refuge Productions.

Genova, N. De (2015), 'Migrant crisis/refugee crisis', in N. De Genova and M. Tazzioli (eds), Europe/Crisis: New Keywords of 'the Crisis' in and of 'Europe': 
New Keyword Collective, New York: Zone Books, http://nearfuturesonline.org/europecrisis-new-keywords-of-crisis-in-and-of-europe-part-2/. Accessed 1 August 2016.

Heller, C. (2015), 'Crisis', in N. De Genova and M. Tazzioli (eds), Europe/Crisis: New Keywords of 'the Crisis' in and of 'Europe': New Keyword Collective, New York: Zone Books, http://nearfuturesonline.org/europecrisis-newkeywords-of-crisis-in-and-of-europe-part-2/. Accessed 1 August 2016.

hooks, bell (1990), 'Marginality as a site of resistance', in R. Ferguson et al. (eds), Out There: Marginalization and Contemporary Cultures, Cambridge, MA: MIT, pp. 341-44.

Ilker, A., Kron, S., Schilliger, S., Schwiertz, H. and Stierl, M. (2015), 'Struggles of migration as in-/visible politics', Movements. Journal für kritische Migrationsund Grenzregimeforschung, 1:2, pp. 1-17.

Mazzara, F. (2015), 'Spaces of visibility for the migrant of Lampedusa: The counter narrative of the aesthetics discourse', Italian Studies, 70:4, pp. 449-64.

Mezzadra, S. (2011), 'The gaze of autonomy: Capitalism, migration, and social struggles', in V. Squire (ed.), The Contested Politics of Mobility: Borderzones and Irregularity, London: Routledge, pp. 121-42.

Muneroni, S. (2015), 'Memorialization and representation of immigrants in contemporary Italy: The case of Mimmo Paladino's monument "Gateway to Lampedusa/Gateway to Europe"', Crossings: Journal of Migration $\mathcal{E}$ Culture, 6:2, pp. 233-45.

Papadopoulos, D., Stephenson, D. and Tsianos, V. (2008), Escape Routes: Control and Subversion in the XXI Century, London: Pluto Press.

Perkowski, N. (2016), ‘Deaths, interventions, humanitarianism, human rights in the Mediterranean "migration crisis"', Mediterranean Politics, 21:2, pp. 331-35.

Pezzani, L. and Heller, C. (2013), 'A disobedient gaze: Strategic interventions in the knowledge(s) of maritime borders', Postcolonial Studies, 16:3, pp. 289-98.

Rancière, J. (2004), The Politics of Aesthetics, London and New York: Bloomsbury.

- (2009), Aesthetics and its Discontents, Cambridge: Polity Press.

(2010), Dissensus: On Politics and Aesthetics, London and New York: Bloomsbury.

Rinelli, L. (2016), African Migrants and Europe: Managing the Ultimate Frontier, London and New York: Rotledge.

Rosi, Gianfranco (2016), Fuocoammare, Roma: Stemal Entertainment.

Rygiel, S. (2011), 'Bordering solidarities: Migrant activism and the politics of movement and camps at Calais', Citizenship Studies, 15:1, pp. 1-19.

Stierl, M. (2015), 'Numbers (or the spectacle of statistics in the production of "crisis")', in N. De Genova and M. Tazzioli (eds), Europe/Crisis: New Keywords of 'the Crisis' in and of 'Europe': New Keyword Collective, New York: Zone Books, http://nearfuturesonline.org/europecrisis-new-keywords-of-crisisin-and-of-europe-part-2/. Accessed 1 August 2016.

Tazzioli, M. (2015a), 'Humanitarian crisis', in N. De Genova and M. Tazzioli (eds), Europe/Crisis: New Keywords of 'the Crisis' in and of 'Europe': New Keyword Collective, New York: Zone Book, http://nearfuturesonline.org/ europecrisis-new-keywords-of-crisis-in-and-of-europe-part-5/. Accessed 1 August 2016.

(2015b), Spaces of Governability: Autonomous Migration and the Arab Uprising, London: Rowman \& Littlefield International. 
(2015c), 'Which Europe? Migrants' uneven geographies and countermapping at the limits of representation', Movements. Journal für kritische Migrations- und Grenzregimeforschung, 1:2, pp. 1-19.

Tazzioli, M. and Garelli, G. (2016), 'The EU hotspot approach in Lampedusa', Open Democracy, https://www.opendemocracy.net/can-europe-makeit/glenda-garelli-martina-tazzioli/eu-hotspot-approach-at-lampedusa. Accessed 1 August 2016.

Ticktin, M. (2011), Casualities of Care: Immigration and the Politics of Humanitarianism in France, Berkeley: University of California Press.

Walters, W. (2011), 'Foucault and frontiers: Notes on the birth of the humanitarian border', in U. Bröckling, S. Krasmann and T. Lemke (eds), Governmentality: Current Issues and Future Challenges, New York: Routledge, pp. 138-64.

Watson, S. D. (2009), The Securitization of Humanitarian Migration: Digging Moats and Sinking Boats, London: Routledge.

\section{SUGGESTED CITATION}

Mazzara, F. (2016), 'Subverting the narrative of the Lampedusa borderscape', Crossings: Journal of Migration \& Culture, 7: 2, pp. 135-147, doi: 10.1386/ cjmc.7.2.135_1

\section{CONTRIBUTOR DETAILS}

Federica Mazzara is Senior Lecturer in Intercultural Communication at the University of Westminster. Her research revolves around migration in relation to cultural expression, with a focus on visual art. She is currently writing a book for Peter Lang on Lampedusa and the aesthetics of subversion. She has previously published on the literature of migration and on the relationship between literature and painting. Her recent publications include the following: 'Spaces of visibility for the migrants of Lampedusa', in L. Baracco (ed.), 'Re-imagining Europe's borderlands: The social and cultural impact of undocumented migrants on Lampedusa', Italian Studies, 70: 4 (2015), pp. 449-64; 'Performing a postmigration cinema in Italy. Corazones de Mujer by K. Kosoof', Modern Italy, 18.1 (January 2013), pp. 41-53.

Contact: Department of Modern Languages and Cultures, University of Westminster, 309 Regent Street, London W1B 2UW, UK.

E-mail: f.mazzara@westminster.ac.uk

Federica Mazzara has asserted her right under the Copyright, Designs and Patents Act, 1988, to be identified as the author of this work in the format that was submitted to Intellect Ltd. 


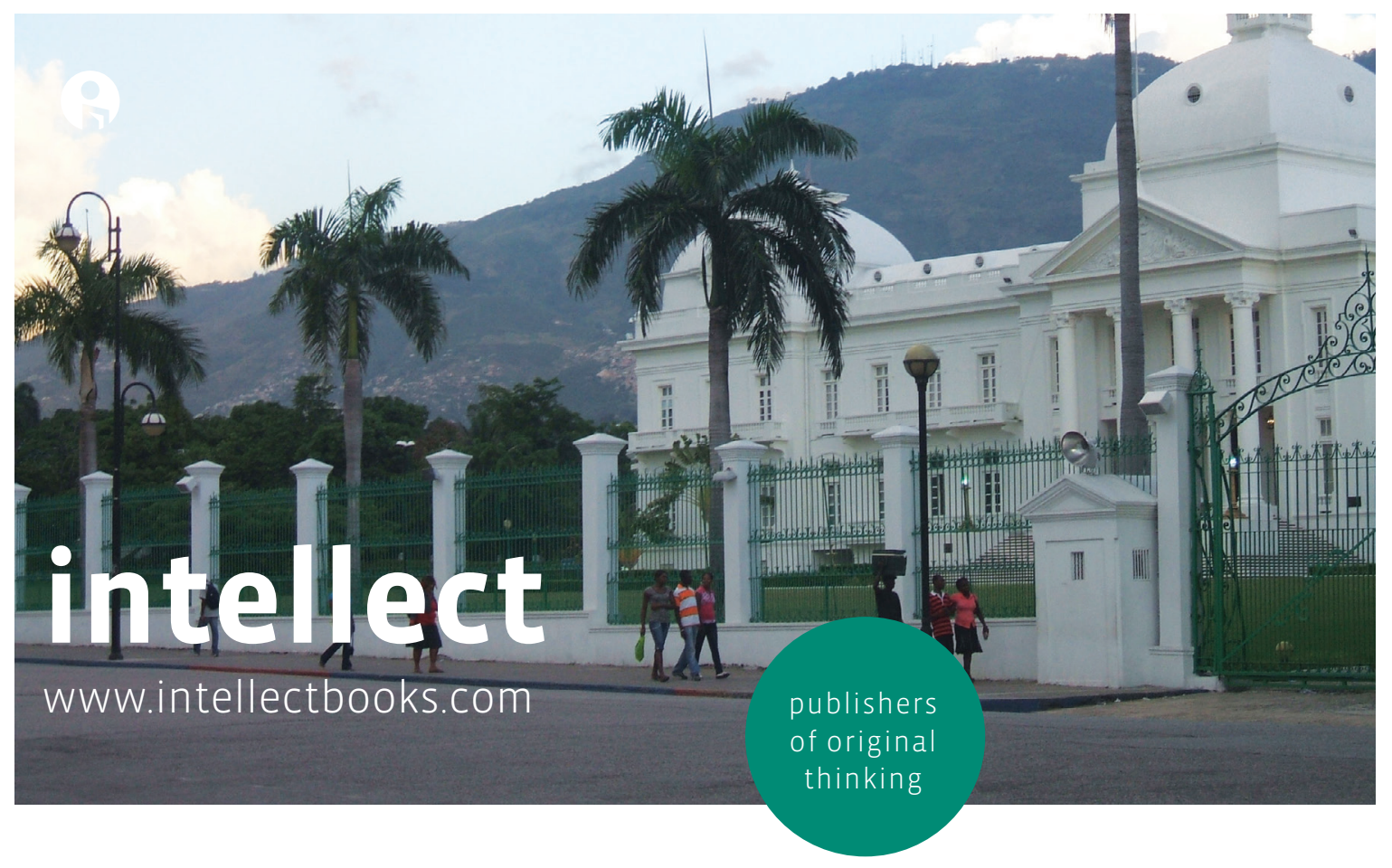

\section{International Journal of Francophone Studies}

ISSN 1368-2679 | Online ISSN 1758-9142

4 issues per volume | Volume 16, 2013

\section{Aims and Scope}

The premiere bilingual and world-leading outlet for Francophone postcolonial studies, Francophone Studies is an international interdisciplinary journal which enables extensive opportunities for the study of 'France outside France'. It promotes groundbreaking research on the fundamental nature of the relationship between colonial history and culture, and postcolonial cultural production, including literature and the visual and performing arts. Interests have developed to include the impact of modern French culture in global world culture and the impact of this global culture on French hexagonal culture, and subsequent intellectual, cultural and political developments.

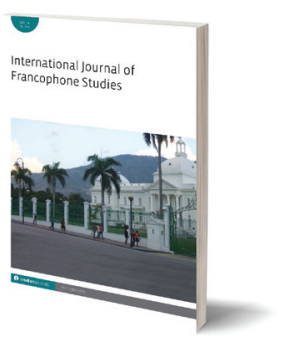

Founder and Editor

Kamal Salhi

University of Leeds

K.salhi@leeds.ac.uk

\section{Deputy Editor}

(North America Editorial)

Raija Koski

University of W. Ontario

\section{Call for Papers}

The journal, which applies a very rigorous peer-review process, invites submissions that pursue the methods and methodologies by which we attempt to approach original research in Francophone postcolonial studies. Articles that encourage challenging debate on problem areas within the field are welcomed to the journal's open forum, as are high-quality articles usually published as peripheral items in journals from other disciplines. Proposals for special or themed issues are also particularly welcomed. 